\title{
AKT3 Gene Mutation
}

National Cancer Institute

\section{Source}

National Cancer Institute. AKT3 Gene Mutation. NCI Thesaurus. Code C150442.

A change in the nucleotide sequence of the AKT3 gene. 